\title{
Attention Deficit Hyperactivity Disorder: definition, contexts, neural correlates and clinical strategies
}

\section{Giulio Perrotta}

Director of the Department of Criminal and Investigative Psychology UNIFEDER, Italy.

Corresponding Author: Giulio Perrotta, Director of the Department of Criminal and Investigative Psychology UNIFEDER, Italy. Email: giuliosr1984@hotmail.it

Received date: 20 August, 2019; Accepted date: 28September, 2019; Published date: 18 October, 2019

Citation: Giulio Perrotta (2019), Attention Deficit Hyperactivity Disorder: definition, contexts, neural correlates and clinical strategies j Addi Adol Beh 2(1) Doi: 10.31579/2688-7517/011

Copyright: (02019 Giulio Perrotta. This is an open-access article distributed under the terms of The Creative Commons. Attribution License, which permits unrestricted use, distribution, and reproduction in any medium, provided the original author and source are credited.

\begin{abstract}
Starting from the definition of "Attention Deficit and Hyperactivity Disorder" (ADHD), we proceeded to list the individual forms envisaged by the DSM-V, with a series of focus on clinical, neuropsychological and therapeutic profiles, concluding the analysis on the context resolution of the problems deriving from the disturbance in question.

Keywords: psychology, neuroscience, prefrontal cortex, frontal lobe, temporal lobe, limbic system, attention deficit hyperactivity disorder, hyperactivity, attention, ADHD, psychotherapy, psychopharmacology, benzodiazepines, antidepressants, mood stabilizers, strategic approach.
\end{abstract}

\section{Introduction}

\section{Definition and clinical context of attention deficit hyperactivity disorder}

Attention deficit hyperactivity disorder (ADHD) is, according to the DSM-V [1], a neurodevelopmental disorder characterized by problems in maintaining attention, hyperactivity and / or difficulty in controlling one's behavior (due to the impulsiveness), which does not appear to be appropriate to the age of the person [2].

The first description known to date of symptoms attributable to an attention deficit disorder was made in 1775 by Melchior Adam Weikard, the German physician and philosopher. [3] Sir Alexander Crichton, in 1798, called it "mental restlessness" [11]. Attention deficit hyperactivity disorder (ADHD) was also described in 1902 by George Still [4]. The terminology used to describe the condition has changed over time: in the first edition of the Diagnostic and Statistical Manual of Mental Disorders [DSM-I] (1952) "minimum brain dysfunction" was defined, in DSM-II (1968) it took the name instead of "hyperkinetic reaction in childhood", DSM-III (1980) called it "attention deficit disorder, with or without hyperactivity". This terminology was changed in 1987 with the DSM-III while the DSM-IV in 1994 divided the diagnosis into three subtypes: inattentive type, hyperactive/impulsive type and the combined type. [5] [6] [7]

Due to its typical characteristics, ADHD leads to a higher rate of school and work abandonment than the average; other consequences of this disorder can be anxiety-depressive disorders, oppositional-provocative disorders, conduct disorders, sleep and circadian rhythm disorders, more frequent divorces, higher risk of road accidents and pathological addictions. [8]

Controversial instead is the theme that correlates the disorder in question and the high IQ. Most studies found similar changes regardless of IQ, with high repetition rates and social difficulties. Furthermore, more than half of people with high IQ who have ADHD have also developed a major depressive disorder or an oppositional defiant disorder at some point in their lives. Generalized anxiety disorder, separation anxiety disorder and social phobia are further common conditions. There is some evidence that individuals with high IQ and ADHD have a reduced risk of substance abuse and antisocial behaviour than children with low or medium IQ and ADHD. Children, adolescents and adults with high IQ can have an incorrect measure of their level of intelligence during a standard assessment and therefore may require complete analysis. [9]

In general, the clinical symptoms generally appear before the age of twelve, must have persisted for at least six months and must cause problems in at least two socio-environmental and cultural contexts of the subject affected by the disorder [10].

Based on the DSM-5 criteria, which we will analyze later in detail, we can distinguish three typical ADHD manifestations:

a) $A D H D$ with predominant inattention (typical features are being easily distracted, poor memory, daydreaming, disorganization, inability to sustain attention, and difficulty in completing activities - procrastination); 
b) ADHD with predominant hyperactivity/impulsivity (typical features are excessive restlessness and agitation, hyperactivity, difficulty in waiting and sitting and listening or paying attention to a topic of no primary interest);

c) combined $A D H D$ (between the forms "a" and "b").

Therefore, ADHD can present itself in three distinct forms that often have very different characteristics. For example, in those who present the variant with a predominance of inattention that has few or no symptoms of hyperactivity, restlessness and impulsiveness, ADHD may not be noticed [11]; however, however, it is possible that over the years the diagnosis of ADHD evolves and moves from one event to another [12], as several researches over the decades have shown that at least half of people with ADHD in childhood and pre-adolescent age continue to suffer even in adolescence and adulthood, with a percentage that varies from two to five (especially in adulthood) [13] [14], instead children who present an ADHD with characteristics of hyperactivity tend to show less marked symptoms, for example, internal restlessness, tension, nervousness, during adolescence and adulthood, or no longer showing these symptoms, but often continuing to have inattentive and / or impulsive symptoms; these are the most significant symptoms of ADHD in adulthood [15].

It is, therefore, necessary to identify a persistent pattern of inattention and/or hyperactivity-impulsivity that interferes with functioning or development, as characterized by (1) and/or (2):

1. Inattention. Six (or more) of the following symptoms have persisted for at least six months with an intensity incompatible with the level of development and which has a direct negative impact on social and educational / work activities:

- Often fails to pay attention to details or makes careless mistakes in schoolwork, work or other activities (e.g., neglects or omits details, work is not accurate).

- He often has difficulty maintaining attention on tasks or gaming activities (e.g., he has difficulty staying focused during a lesson, a conversation or an extended reading).

- He often does not seem to listen when he is spoken to directly (for example, the mind seems elsewhere, even in the absence of apparent distractions).

- He often does not follow the instructions and does not complete the schoolwork, duties or duties at the workplace (e.g., he begins the tasks but quickly loses concentration and is easily distracted).

- He often has difficulty in organizing himself in tasks and activities (for example, difficulties in managing sequential tasks; difficulty in keeping materials and objects in order; disorderly, disorganized work; inadequately manages time, fails to meet deadlines).

- Often avoids, dislikes or is reluctant to engage in tasks that require protracted mental effort (e.g., schoolwork or homework; for older teenagers and adults, reporting, filling out forms, reviewing documents).

- $\quad$ It often loses the objects necessary for homework or activities (e.g., school supplies, pencils, books, tools, wallets, keys, documents, glasses, mobile phone).

- $\quad \mathrm{He}$ is often easily distracted by external stimuli (for older adolescents and adults, jumbled thoughts may be included).
- $\quad$ He is often careless in daily activities (e.g., doing chores, running errands, for older teenagers and adults, remembering to make a phone call; paying bills; making appointments).

\section{Hyperactivity and impulsivity. Six (or more) of the following symptoms}

persist for at least months with an intensity that is incompatible with the level of development, and that has a direct negative impact on social and educational / work activities (for older adolescents and adults - age of seventeen and beyond - at least five symptoms are required):

- Often shakes or beats hands and feet or squirms on the chair.

- It often leaves its place in situations where one should remain seated (e.g., leave the place in the classroom, in the office or another workplace, or in other situations that require staying in place).

- Often runs around and jumps in situations where doing so is inappropriate. (In adolescents and adults it may be limited to feeling restless).

- He is often unable to play or play quietly.

- It is often "under pressure", acting as if it were "driven by an engine" (e.g., it is unable to remain still, or feels uncomfortable doing it, for an extended period of time, as in the restaurants, during meetings, can be described by others as a restless person or with whom it is difficult to deal with.

- He often talks too much.

- Often "shoots" an answer before the question has been completed (e.g., completes the sentences spoken by other people; it cannot wait for its turn in the conversation).

- He often has difficulty waiting for his turn (e.g., while waiting in line).

- Often interrupts others or is intrusive to them (e.g., interrupts conversations, games or activities; can start using other people's things without asking or receiving permission; adolescents and adults can enter or take over what they do others).

In short, it must be clear that the symptoms are not only a manifestation of oppositional behaviour, or challenge, hostility or inability to understand tasks or instructions, but a complex disorder with a precise persistent and debilitating symptomatology. Not surprisingly, associated with the disorder in question, we often find problems in interpersonal relationships. [16] [17] [18]

Another central issue of clinical interest is comorbidity. Other disorders such as anxiety or depression may be associated with ADHD, and such psychopathological circumstances can greatly complicate diagnosis and treatment. Several studies suggest that depression in ADHD appears to increase in children in parallel with their growth, with a higher rate of growth in girls than in boys. When a mood disorder complicates ADHD, it would be more desirable to treat the mood disorder earlier even if the parents of children who have ADHD often want ADHD treated first, since the response to treatment is faster. [19]

Inattention and hyperactive behaviour are not the only problems in those with ADHD. ADHD exists alone, with no other pathology, in about onethird of people. Many coexisting conditions require other types of treatment and should be diagnosed separately instead of being grouped into the diagnosis of ADHD. [20] Some of the conditions often associated are: 
- oppositional-provocative disorder and conduct disorder, which occur in approximately $20-50 \%$ of ADHD cases [21], characterized by antisocial behaviour such as stubbornness, aggression, anger, falsity, 1 use of lies and participation in crimes; [22]

- borderline personality disorder; [23]

- post-traumatic stress disorder; [24]

- mood disorders (especially bipolar disorder and major depressive disorder): children diagnosed with a combined subtype have been shown to suffer from this type of disorder: $25 \%$ of children with ADHD have bipolar disorder. [25] Children with this combination may show more aggression and behavioural problems than those with ADHD alone. [26] Adults with ADHD who also have bipolar disorder require careful evaluation to manage both conditions; [27]

- avoidant personality disorder; [28] [29]

- anxiety disorders: it was found to be common in girls diagnosed with a subtype characterized by ADHD inattention; [30]

- obsessive-compulsive disorder: it is believed that there is a common genetic component between this disorder and ADHD; [31]

- Specific learning disabilities were found in about 20-30\% of children with ADHD. Learning difficulties can include language and developmental disorders. [32] However, ADHD is not considered a learning disability but often causes scholastic difficulties; [33]

- Tourette syndrome was found more frequently in individuals with ADHD; [34]

- substance use disorders. [35] Adolescents and adults with ADHD see their risk of developing problem drug use increased, the most common of which are alcohol and cannabis. [36] The reason for this may be due to an altered reward pathway in the brain. [37] [38]

- restless legs syndrome is common in patients with ADHD and is often due to iron deficiency (anaemia). [39] [40] However, this condition can be a part of $\mathrm{ADHD}$ and requires careful evaluation to distinguish the two disorders; [41]

- autism spectrum disorders; [42]

- sleep disorders and circadian rhythm. [43] [44]

- language problems in people with ADHD can include auditory processing disorders, difficulty following instructions, slow processing of written and spoken the language, listening difficulties and weakness in reading comprehension. [45]

\section{The neural correlates in attention deficit hyperactivity disorder}

The etiopathology of ADHD is unclear, as there are currently several competing explanations [46]; however, the neurobiological matrix [57] [58] [59] and traumatic [60] are evident. It has been observed that in children with ADHD there is a general reduction in the volume of the brain, with a proportionally more significant decrease in the left side of the prefrontal cortex: it seems that brain pathways connecting the prefrontal cortex and the striatum are also involved in the condition. [47]. This suggests that inattention, hyperactivity and impulsivity may reflect a frontal lobe dysfunction with additional regions, such as the cerebellum, that may be implicated. [48] Other attention-related brain structures were found to be different between people with and without ADHD. [49] [50] Previously, it was thought that the high number of dopamine transporters in subjects with ADHD was part of its pathophysiology, but it appears that these are caused by adaptation to exposure to stimulants. [51] People with ADHD may have a low excitation threshold and compensate for this with more stimulation, a condition that in turn causes loss of attention and increases hyperactive behaviour: the reason for this is due to anomalies in the way the dopamine system responds to stimulation. [52] There may also be anomalies in the adrenergic, serotoninergic and cholinergic or nicotinic pathways. [53] [54] Another theory suggests that the symptoms derive from a deficit in executive functions: these alterations affect above all the brain areas used for attention functions, such as the prefrontal cortex, the cerebellum and the basal ganglia. [55]

Barkley (1998), to complete the etiological picture, proposed a list of risk factors, sorted by level of importance, associated with the genesis of ADHD:

1) presence of psychological disorders in family members, in particular, ADHD;

2) abuse of cigarettes and alcohol of the mother during pregnancy;

3) absence of a parent or inadequate education;

4) health problems or developmental delays of the child;

5) early onset of high levels of motor activity;

6) critical and/or managerial attitudes of the mother during the early years of the child.

Contrasted to the risk factors (Campbell, 1990), however, a list of factors that we could define protective was built, as they help the boy to limit the negative results of ADHD, among these we remember:

1) good health of the child shortly after birth;

2) excellent cognitive abilities of the child (in particular linguistic);

3) family stability.

Then in 1990, Zametkin conducted a study on glucose metabolism in the brains of adult ADHD patients and compared it to healthy individuals. The PET scan shows cerebral glucose consumption in a given activity, left in a person without ADHD and right in one with. The study was the first major functional neuroimaging study in ADHD and formed the basis for many other studies. The specific results, however, were only partially reproduced. [61] [62]

Recently, a research conducted by over eighty scholars on over twentyfive thousand patients has fueled the hypothesis, already travelled by other researchers in previous years, of a probable genetic matrix [63] in the aetiology of the disorder in question, to be added to the other causes already set out. Therefore the idea that ADHD is a disorder with a solid biological basis, in which genetics has a large part, is undeniable. In essence, twelve DNA sequences, whose common genetic variants represent as many as twenty-one per cent of the risk of ADHD, are strongly correlated with the risk of developing attention deficit hyperactivity disorder (ADHD). Some of these fragments coincide with specific genes, including the FOXP2, DUSP6 and SEMA6D genes. FOXP2, one of the most studied genes due to its involvement in language development and already suspected of contributing to ADHD, encodes a protein with a central role in the formation of synapses between neurons and in learning. DUSP6 is instead involved in the control of communication between dopaminergic neurons (i.e. which use dopamine as the primary messenger): the dopaminergic system is precisely the target of the most 
common ADHD drug therapies. Finally, the SEMA6D gene, expressed in the brain during embryonic development, could play a significant role in the creation of neural connections.

\section{Clinical strategies for the management of the disorder}

For over a decade the thesis that establishes the best method for treating ADHD is peaceful: a clever combination of behavioural therapies, lifestyle changes, clinical-psychological interventions and drugs [64], although treatment can improve the condition in the long term but is unable to eliminate adverse pathological outcomes. [65]

Concerning psychological and behavioural interventions, always for a decade, the effectiveness of therapies centred on cognitive and behavioural profiles has been demonstrated [66]. The psychological therapies used to treat ADHD include psychoeducational interventions, coaching techniques, psychotherapy with a cognitive-behavioural approach, mindfulness, family and systemic therapies, interpersonal psychotherapies, training or implementation of social skills and neurofeedback [67]. Family therapy has also been shown to be usefully used in the treatment of ADHD [68], although such an approach may be difficult in reality, familiar with divorced parents [69]. It has been shown that parental training and patient education interventions can lead to short-term benefits [70]. Few high-quality studies prove the efficacy of family therapy for ADHD, but the evidence shows that such interventions have better results than placebo [71].

Compared to drugs, the first-choice drug treatment is implemented through the use of stimulant drugs, as they act to improve the neurotransmission of dopamine and norepinephrine, neurotransmitters which are associated with essential functions of inhibition and brain modulation, in essence, the brakes of the brain; however "non-stimulants" such as atomoxetine (Strattera), clonidine, guanfacine and bupropion (Wellbutrin) can be used as an alternative [72]. The stimulant drugs used are: methylphenidate, amphetamine, dextroamphetamine and lisdestro amphetamine [73]. The use of psychostimulants to treat the condition was first described in 1937 [74] where the mixture of benzedrine and amphetamine was the first drug therapy suggested and approved for the treatment of ADHD in the United States. The use of prescription drugs is not recommended for preschool children since the long-term effects of this therapy are not known in this age group [75]. Atomoxetine, due to the lack of the risk of abusing it, may be preferable in those who are at risk of making excessive use of stimulants [76]. However, drug therapy is not applied alone but is accompanied by other interventions on the person and the family.

Dietary changes may also be beneficial [77], with evidence supporting the use of free fatty acids and reduced exposure to food colouring [78]. Further suggested integration refers to zinc, as a shortage of this mineral has often been found [79]. Iron, magnesium and iodine deficiency may also affect ADHD symptoms [80] [81]. Finally, there is compelling evidence about the benefit of taking, as a dietary supplement, omega 3, 6 and 9 [82] [83].

\section{Conclusions}

Attention deficit hyperactivity disorder (ADHD) is one of the most frequent chronic neuropsychiatric disorders of onset in the developmental age, characterized by inattention, impulsivity and motor hyperactivity which compromises many stages of development and social integration of children. It is a heterogeneous and complex, multifactorial disorder that coexists with another or other disorders in $70-80 \%$ of cases, a factor that aggravates the symptoms, making both diagnosis and therapy complex. Those most frequently associated are the oppositionalprovocative disorder and conduct disorders, specific learning disabilities (dyslexia, dysgraphia, etc.), anxiety disorders and, less frequently, depression, obsessive-compulsive disorder, tic disorder, bipolar disorder.

Through neuroimaging techniques (Functional Magnetic Resonance and Positron Emission Tomography) and molecular genetic studies, it was possible to highlight that $\mathrm{ADHD}$ is a disorder of biological origin of the prefrontal cortex and of the nuclei of the base that involves an alteration in the elaboration of responses to environmental stimuli and concentration skills.

The last decades of research of this disorder have led to the consideration and study of numerous factors at its origin (in fact it is a multifactorial disorder) and among these genetic factors (since it is a polygenic disorder with an inheritance factor of over $75 \%$, many are the candidate genes that are the subject of studies of the dopamine and noradrenaline neurotransmission system which are associated with essential functions of inhibition and cerebral modulation), cerebral morphological factors (frontal cortex, caudate nucleus and pale globe are smaller in ADHD children), prenatal and perinatal factors and traumatic factors. In this various complex of causes, there is still to be considered that the activation of the predisposition to the disorder is probably also modulated by environmental factors (family, education, social contexts, etc.). Therefore, it can be excluded that ADHD is a disorder linked exclusively to childhood and pre-adolescent age.

Precisely because it is a multifactorial disorder, the treatment will necessarily consist of the simultaneous use of psychological therapy, educational treatment and targeted pharmacotherapy.

\section{References}

1. American Psychiatric Association, Diagnostic and Statistical Manual of Mental Disorders, 5th, Arlington, American Psychiatric Publishing, 2013, pp. 59-65, ISBN 978-0-89042-555-8

2. Sroubek A, Kelly $\mathrm{M}$, Li $\mathrm{X}$, Inattentiveness in attentiondeficit/hyperactivity disorder, in Neuroscience Bulletin, vol. 29, $\mathrm{n}^{\circ} 1$, February 2013, pp. 103-10, DOI:10.1007/s12264-012-12956, PMC 4440572, PMID 23299717

3. Palmer ED, Finger S, An early description of ADHD (inattentive subtype): Dr Alexander Crichton and 'Mental restlessness' (1798), in Child and Adolescent Mental Health, vol. 6, n 2, Maggio 2001, pp. 66-73, DOI:10.1111/ 1475-3588.00324

4. Andrew Crichton, An inquiry into the nature and origin of mental derangement: comprehending a concise system of the physiology and pathology of the human mind and a history of the passions and their effects, United Kingdom, AMS Press, 1798, p. 271

5. $A D H D$, Throughout the Years (PDF), Center For Disease Control and Prevention

6. Lange, K.W. et al.: The history of attention deficit hyperactivity disorder. In: Attention Deficit Hyperactivity Disorders, 2(4):241-55. DOI: $10.1007 / \mathrm{s} 12402-010-0045-8$

7. J. Gordon Millichap, Definition and History of $A D H D$, in Attention Deficit Hyperactivity Disorder Handbook, Springer Verlag Gmbh, April 2010, pp. 2-3, ISBN 978-1-4419-1409-5

8. SJ. Kooij, S. Bejerot; A. Blackwell; H. Caci; M. Casas-Brugué; PJ. Carpentier; D. Edvinsson; J. Fayyad; K. Foeken; M. Fitzgerald; V. Gaillac, European consensus statement on diagnosis and treatment of 
adult ADHD: The European Network Adult ADHD., in BMC Psychiatry, vol. 10, 2010, p. 67, DOI:10.1186/1471-244X-1067, PMID 20815868

9. Antshel, KM, Attention-Deficit Hyperactivity Disorder in the context of a high intellectual quotient/giftedness, in Dev Disabil Res Rev, vol. $14, \quad \mathrm{n}^{\mathrm{o}} \quad 4, \quad 2008, \quad$ pp. 2939, DOI:10.1002/ddrr.34, PMID 19072757

10. Mina K. Dulcan e MaryBeth Lake, Axis I Disorders Usually First Diagnosed in Infancy, Childhood or Adolescence: Attention-Deficit and Disruptive Behavior Disorders, Concise Guide to Child and Adolescent Psychiatry, 4th illustrated, American Psychiatric Publishing, 2011, pp. 34, ISBN 978-1-58562-416-4

11. Kenneth D. Gadow, Deborah A. G. Drabick e Jan Loney, Comparison of ADHD symptom subtypes as source-specific syndromes, in Journal of Child Psychology and Psychiatry, and Allied Disciplines, vol. 45, $\mathrm{n}^{\mathrm{o}}$ 6, 2004-9, pp. 11351149, DOI:10.1111/j.1469-7610.2004.00306.x

12. Jonathan Williams e Eric Taylor, The evolution of hyperactivity, impulsivity and cognitive diversity, in Journal of the Royal Society Interface, vol. 3, $\mathrm{n}^{\mathrm{o}}$ 8, 22 Giugno 2006, pp. 399-413, DOI:10.1098/rsif.2005.0102

13. Kooij SJ, Bejerot S, Blackwell A, Caci H, Casas-Brugué M, Carpentier PJ e al., a European consensus statement on diagnosis and treatment of adult ADHD: The European Network Adult ADHD, in BMC Psychiatry, vol. 10, 2010, p. 67

14. Ginsberg Y, Quintero J, Anand E, Casillas M e Upadhyaya HP, Underdiagnosis of attention-deficit/hyperactivity disorder in adult patients: a review of the literature, in Prim Care Companion CNS Disord, vol. 16, 2014

15. National Collaborating Centre for Mental Health (UK), Attention deficit hyperactivity disorder: diagnosis and management of $A D H D$ in children, young people, and adults, National Collaborating Centre for Mental Health (Great Britain), National Institute for Health and Clinical Excellence (Great Britain), British Psychological Society., Royal College of Psychiatrists., Leicester, British Psychological Society, 2009, p. 17, ISBN 978-1-85433-471-

8, OCLC 244314955, PMID 22420012

16. WE. Pelham, R. Milich, Peer relations in children with hyperactivity/attention deficit disorder, in J Learn Disabil, vol. $17, \mathrm{n}^{\circ}$ 9, November 1984, pp. 560-7, PMID 6389737

17. CL. Carlson, BB. Lahey; CL. Frame; J. Walker; GW. Hynd, Sociometric status of clinic-referred children with attention deficit disorders with and without hyperactivity, in J Abnorm Child Psychol, vol. 15, no 4, December 1987, pp. 537-47, PMID 3437089

18. Pelham W, Bender M., Peer relationships in hyperactive children: description and treatment. Adv in Learning Behav Disabilities. 1982;1:365-436

19. Brunsvold GL, Open G, Comorbid Depression in ADHD: Children and Adolescents, in Psychiatric Times, vol. 25, $\mathrm{n}^{\circ}$ 10, 2008

20. Walitza S, Drechsler R, Ball J, [The school child with ADHD], in Ther Umsch, vol. 69, $\mathrm{n}^{\circ}$ 8, Agosto 2012, pp. 467-473, DOI:10.1024/0040-5930/a000316, PMID 22851461

21. McBurnett K, Pfiffner LJ, Treatment of aggressive ADHD in children and adolescents: conceptualization and treatment of comorbid behaviour disorders, in Postgrad Med, vol. 121, $\mathrm{n}^{\circ}$ 6, Novembre 2009 , pp.

DOI:10.3810/pgm.2009 11.2084, PMID 19940426

22. Krull, K.R., Evaluation and diagnosis of attention deficit hyperactivity disorder in children, Update, 2007

23. Philipsen A, Differential diagnosis and comorbidity of attentiondeficit/hyperactivity disorder $(A D H D)$ and borderline personality disorder (BPD) in adults, in European Archives of Psychiatry and Clinical Neuroscience, 256 Suppl 1, September 2006, pp. i42-6, DOI:10.1007/s00406-006 1006-2, PMID 16977551
24. Kevin M. Antshel, Prashant Kaul e Joseph Biederman, Posttraumatic stress disorder in adult attention-deficit/hyperactivity disorder: clinical features and familial transmission, in The Journal of Clinical Psychiatry, vol. 74, $\mathrm{n}^{\mathrm{o}} \quad 3, \quad 2013-3, \quad$ pp. e197204, DOI:10.4088/JCP.12m07698.

25. Bauermeister, J., Shrout, P., Chávez, L., Rubio-Stipec, M., Ramírez, R., Padilla, L., et al. (2007, August). ADHD and gender: are risks and sequela of $A D H D$ the same for boys and girls?. Journal of Child Psychology \& Psychiatry, 48(8), 831-839. Retrieved February 17, 2009, DOI:10.1111/j.1469-7610.2007.01750.x

26. McBurnett K, Pfiffner LJ, Treatment of aggressive ADHD in children and adolescents: conceptualization and treatment of comorbid behaviour disorders, in Postgrad Med, vol. 121, $\mathrm{n}^{\circ}$ 6, November 2009, pp. 158-165, DOI:10.3810/pgm.2009.11.2084, PMID 19940426

27. Krull, K.R., Evaluation and diagnosis of attention deficit hyperactivity disorder in children, Update, 5Dec 52007

28. Philipsen A, Differential diagnosis and comorbidity of attentiondeficit/hyperactivity disorder (ADHD) and borderline personality disorder (BPD) in adults, in European Archives of Psychiatry and Clinical Neuroscience, 256 Suppl 1, September 2006, pp. i42-6, DOI:10.1007/s00406-006-1006-2, PMID 16977551

29. Kevin M. Antshel, Prashant Kaul e Joseph Biederman, Posttraumatic stress disorder in adult attention-deficit/hyperactivity disorder: clinical features and familial transmission, in The Journal of Clinical Psychiatry, vol. 74, $\mathrm{n}^{\mathrm{o}}$ 3, 2013-3, pp. e197204, DOI:10.4088/JCP.12m07698. URL consultato il 29 Agosto 2018

30. Bauermeister, J., Shrout, P., Chávez, L., Rubio-Stipec, M., Ramírez, R., Padilla, L., et al. (2007, August). ADHD and gender: are risks and sequela of $A D H D$ the same for boys and girls?. Journal of Child Psychology \& Psychiatry, 48(8), 831-839. Retrieved February 17, 2009, DOI:10.1111/j.1469-7610.2007.01750.x

31. Baud P, Perroud N, Aubry JM, Bipolar disorder and attentiondeficit/hyperactivity disorder in adults: differential diagnosis or comorbidity, in Rev Med Suisse, vol. 7, n 297, Giugno 2011, pp. 1219-1222, PMID 21717696

32. Yoldas C, Dogan B, Kocabas O, Memis CO, Sevincok D, Sevincok L, The importance of avoidant personality in social anxiety disorder with and without attention-deficit/hyperactivity disorder. Atten Defic Hyperact Disord. 2019 Feb 14. DOI: 10.1007/s12402-019-00291-x

33. Ibidem (27)

34. Bauermeister, J., Shrout, P., Chávez, L., Rubio-Stipec, M., Ramírez, R., Padilla, L., et al. (2007, August). ADHD and gender: are risks and sequela of $A D H D$ the same for boys and girls?. Journal of Child Psychology \& Psychiatry, 48(8), 831-839

35. Eileen Bailey, ADHD and Learning Disabilities: How can you help your child cope with ADHD and subsequent Learning Difficulties? There is a way. Remedy Health Media, LLC

36. Attention Deficit Hyperactivity Disorder (ADHD), on The National Institute of Mental Health (NIMH)

37. National Collaborating Centre for Mental Health, Attention Deficit Hyperactivity Disorder: Diagnosis and Management of ADHD in Children, Young People and Adults, British Psychological Society, 2009, pp. 19-27, 23, 38, 130, 133, 317, ISBN 978-1-85433-471-8

38. Wilens TE, Morrison NR, The intersection of attentiondeficit/hyperactivity disorder and substance abuse, in Curr Opin Psychiatry, vol. 24, $\mathrm{n}^{\circ}$ 4, luglio 2011, pp. 280285, 956, PMC 3435098, PMID 21483267

39. Merino-Andreu M, Attention deficit hyperactivity disorder and restless legs syndrome in children, in Rev Neurol, 52 Suppl 1, marzo 2011, pp. S85-95, PMID 21365608

40. Picchietti MA, Picchietti DL, Advances in pediatric restless legs syndrome: Iron, genetics, diagnosis and treatment, in Sleep Med., vol. $11, \mathrm{n}^{\circ} 7$, agosto 2010 , pp. 643651, DOI:10.1016/j.sleep.2009 11.014, PMID 20620105 
41. Karroum E, Konofal E, Arnulf I, Restless-legs syndrome, in Rev. Neurol. (Paris), vol. 164, 8-9, 2008, pp. 701721, DOI:10.1016/j.neurol.2008.06.006, PMID 18656214

42. Yael Leitner, The Co-Occurrence of Autism and Attention Deficit Hyperactivity Disorder in Children - What Do We Know?, in Frontiers in Human Neuroscience, vol. 8, 29 aprile 2014, DOI:10.3389/fnhum.2014.00268

43. Snitselaar MA, et al. J, Atten Disord, A Sleep and Circadian Rhythmicity in Adult ADHD and the Effect of Stimulants, 2017

44. Tsai MH, Huang YS, Attention-deficit/hyperactivity disorder and sleep disorders in children, in Med. Clin. North Am., vol. 94, $\mathrm{n}^{\circ} 3$, maggio 2010, pp. 615632, DOI:10.1016/j.mcna.2010 03.008, PMID 20451036

45. Greathead, Philippa. Language Disorders and Attention Deficit Hyperactivity Disorder" ADDIS Information Centre. ADDIS, 6Nov 62013

46. Krull, K.R., Evaluation and diagnosis of attention deficit hyperactivity disorder in children, Update, 2007

47. Amy Krain, AL Castellanos e FX Castellanos, Brain development and ADHD, in Clinical Psychology Review, vol. 26, $\mathrm{n}^{\circ}$ 4, 2006, pp. 433-444, DOI:10.1016/j.cpr.2006 01.005, PMID 16480802

48. Amy Krain, AL Castellanos e FX Castellanos, Brain development and ADHD, in Clinical Psychology Review, vol. 26, $\mathrm{n}^{\circ}$ 4, 2006, pp. 433-444, DOI:10.1016/j.cpr.2006 01.005, PMID 16480802

49. Castellanos FX, Proal E, Large-scale brain systems in ADHD: beyond the prefrontal-striatal model, in Trends Cogn. Sci. (Regul. Ed.), vol. 16, $\mathrm{n}^{\mathrm{o}}$ 1, Gennaio 2012, pp. 1726, $\quad$ DOI:10.1016/j.tics.2011.11. 007, PMC 3272832, PMID 22169776

50. Cortese S, Kelly C, Chabernaud C, et al., Toward systems neuroscience of ADHD: a meta-analysis of $55 \mathrm{fMRI}$ studies, in Am $\mathrm{J}$ Psychiatry, vol. 169, $\mathrm{n}^{\mathrm{o}} 10$, ottobre 2012, pp. 103855, DOI:10.1176/appi.ajp 2012. 11101521, PMID 22983386

51. Fusar-Poli P, Rubia K, Rossi G, Sartori G, Balottin U, Striatal dopamine transporter alterations in ADHD: pathophysiology or adaptation to psychostimulants? A meta-analysis, in Am J Psychiatry, vol. 169, $\mathrm{n}^{\circ}$ 3, Marzo 2012, pp. 264-72, DOI:10.1176/appi.ajp 2011.11060940, PMID 22294258

52. Sikström S, Söderlund G, Stimulus-dependent dopamine release in attention-deficit/hyperactivity disorder, in Psychol Rev, vol. 114, $\mathrm{n}^{\mathrm{o}} 4$, ottobre 2007, pp. 1047-75, DOI:10.1037/0033295X.114 4.1047, PMID 17907872

53. SJ. Kooij, S. Bejerot; A. Blackwell; H. Caci; M. Casas-Brugué; PJ. Carpentier; D. Edvinsson; J. Fayyad; K. Foeken; M. Fitzgerald; V. Gaillac, European consensus statement on diagnosis and treatment of adult ADHD: The European Network Adult ADHD., in BMC Psychiatry, vol. 10, 2010, p. 67, DOI:10.1186/1471-244X-1067, PMID 20815868

54. S. Cortese, The neurobiology and genetics of AttentionDeficit/Hyperactivity Disorder (ADHD): what every clinician should know, in Eur J Paediatr Neurol, vol. 16, $\mathrm{n}^{\circ}$ 5, September 2012, pp. 422-33, DOI:10.1016/j.ejpn.2012 01.009, PMID 22306277

55. TE. Brown, ADD/ADHD and Impaired Executive Function in Clinical Practice, in Curr Psychiatry Rep, vol. 10, n ${ }^{\circ}$ 5, ottobre 2008, pp. 407-11, DOI:10.1007/s11920-008 0065-7, PMID 18803914

56. Lionel Bailly, Stimulant medication for the treatment of attentiondeficit hyperactivity disorder: evidence-b(i)used to practice?, in Psychiatric Bulletin, vol. 29, $\mathrm{n}^{\circ}$ 8, The Royal College of Psychiatrists, 2005, pp. 284-287, DOI: 10.1192/pb.29.8.284

57. CG72 Attention deficit hyperactivity disorder (ADHD): full guideline (PDF), NHS, 2008

58. Russel A. Barkley, Attention-Deficit/Hyperactivity Disorder: Nature, Course, Outcomes, and Comorbidity, su continuingedcourses.net.

59. Sherman DK, Iacono WG, McGue MK, Attention-deficit hyperactivity disorder dimensions: a twin study of inattention and impulsivity-hyperactivity, in Journal of the American Academy of Child and Adolescent Psychiatry, vol. 36, n 6, giugno 1997, pp. 74553, DOI:10.1097/00004583-199706000-00010, PMID 9183128

60. Barkley, Russell A., Treating Children and Adolescents with ADHD: An Overview of Empirically Based Treatments, on continuingedcourses.net

61. G. Bush, EM. Valera; LJ. Seidman, Functional neuroimaging of attention-deficit/hyperactivity disorder: a review and suggested future directions., in Biol Psychiatry, vol. 57, 2005, pp. 127384, DOI:10.1016/j.biopsych.2005.01. 034, PMID 15949999.

62. AJ. Zametkin, TE. Nordahl; M. Gross; AC. King; WE. Semple; J. Rumsey; S. Hamburger; RM. Cohen, Cerebral glucose metabolism in adults with hyperactivity of childhood onset., in N Engl J Med, vol. 323, $\mathrm{n}^{\mathrm{o}}$ 20, Novembre 1990, pp. 1361-6, DOI:10.1056/NEJM199011153232001, PMID 2233902

63. Ditte Demontis et al., Discovery of the first genome-wide significant risk loci for attention deficit/hyperactivity disorder, Nature Genetics 51, 63-75 (2019)

64. Jensen PS, Garcia JA, Glied S, Cost-effectiveness of ADHD treatments: findings from the multimodal treatment study of children with $A D H D$, in The American Journal of Psychiatry, vol. 162, $\mathrm{n}^{\circ} 9$, settembre 2005, pp. 162836, DOI:10.1176/appi.ajp.162 9.1628, PMID 16135621

65. M Shaw, Hodgkins, P; Caci, H; Young, S; Kahle, J; Woods, AG; Arnold, LE, A systematic review and analysis of long-term outcomes in attention deficit hyperactivity disorder: effects of treatment and nontreatment, in BMC medicine, vol. 10, 4 settembre 2012, pp. 99, DOI:10.1186/1741-7015-1099, PMC 3520745, PMID 22947230

66. Fabiano GA, Pelham WE, Coles EK, Gnagy EM, Chronis-Tuscano A, O'Connor BC, A meta-analysis of behavioral treatments for attentiondeficit/hyperactivity disorder, in Clinical Psychology Review, vol. 29, $\mathrm{n}^{\mathrm{o}} 2$ 2, Marzo 2009, pp. DOI:10.1016/j.cpr.2008 11.001, PMID 19131150

67. M Arns, de Ridder, S, Strehl, U, Breteler, M, Coenen, A, Efficacy of neurofeedback treatment in ADHD: the effects on inattention, impulsivity and hyperactivity: a meta-analysis, in Clinical EEG and neuroscience: official journal of the EEG and Clinical Neuroscience Society (ENCS), vol. 40, $\mathrm{n}^{\circ}$ 3, Luglio 2009, pp. 180-9, DOI:10.1177/1550059409 04000311, PMID 19715181

68. Family therapy for attention-deficit disorder or attentiondeficit/hyperactivity disorder in children and adolescents, The Cochrane Collaboration, 20 Aprile 2005

69. Wymbs BT, Pelham WE, Molina BS, Gnagy EM, Wilson TK, Greenhouse JB, Rate and predictors of divorce among parents of youths with $A D H D$, in Journal of Consulting and Clinical Psychology, vol. 76, $\mathrm{n}^{\mathrm{o}} 5, \quad$ ottobre 2008, pp. 73544, DOI:10.1037/a0012719, PMC 2631569, PMID 18837591

70. Pliszka S e AACAP Work Group on Quality Issues, Practice parameter for the assessment and treatment of children and adolescents with attention-deficit/hyperactivity disorder, in Journal of the American Academy of Child and Adolescent Psychiatry, vol. 46, $\mathrm{n}^{\circ}$ 7, Luglio 2007, pp. 894-921, DOI:10.1097/chi.0b013e318054e7 24, PMID 17581453

71. Bjornstad G, Montgomery P, Family therapy for attention-deficit disorder or attention-deficit/hyperactivity disorder in children and adolescents, in Gretchen J Bjornstad (a cura di), Cochrane Database Syst Rev, $\mathrm{n}^{\circ} \quad 2,2005$, pp. CD005042, DOI:10.1002/14651858.CD005042.pub2, PMID 158 46741

72. Wigal SB, Efficacy and safety limitations of attention-deficit hyperactivity disorder pharmacotherapy in children and adults, in CNS Drugs, 23 Suppl 1, 2009, pp. 21-31, DOI:10.2165/00023210200923000-00004, PMID 19621975 
73. Sulzer D, Sonders MS, Poulsen NW, Galli A, Mechanisms of neurotransmitter release by amphetamines: a review, in Progress in Neurobiology, vol. 75, $\mathrm{n}^{\mathrm{o}}$ 6, Aprile 2005, pp. 406-33, DOI:10.1016/j.pneurobio.2005.04. 003, PMID 15955613

74. Howland RH, Lisdexamfetamine: a prodrug stimulant for ADHD, in Journal of Psychosocial Nursing and Mental Health Services, vol. 46, nº 8, Agosto 2008, pp. 19-22, PMID 18777964

75. Patrick KS, Straughn AB, Perkins JS, González MA, Evolution of stimulants to treat ADHD: transdermal methylphenidate, in Human Psychopharmacology, vol. 24, $\mathrm{n}^{\circ}$ 1, Gennaio 2009, pp. 1-17, DOI:10.1002/hup.992

76. Greenhill LL, Posner K, Vaughan BS, Kratochvil CJ, Attention deficit hyperactivity disorder in preschool children, in Child and Adolescent Psychiatric Clinics of North America, vol. 17, n² 2, Aprile 2008, pp. 347-66, ix, DOI: 10.1016/j.chc.2007.11.004, PMID 18295150

77. SJ. Kooij, S. Bejerot; A. Blackwell; H. Caci; M. Casas-Brugué; PJ. Carpentier; D. Edvinsson; J. Fayyad; K. Foeken; M. Fitzgerald; V. Gaillac, European consensus statement on diagnosis and treatment of adult ADHD: The European Network Adult ADHD., in BMC Psychiatry, vol. 10, 2010, p. 67, DOI:10.1186/1471-244X-1067, PMID 20815868

78. JT Nigg, Lewis, K; Edinger, T; Falk, M, Meta-analysis of attentiondeficit/hyperactivity disorder or attention-deficit/hyperactivity disorder symptoms, restriction diet, and synthetic food color additives, in Journal of the American Academy of Child and Adolescent Psychiatry, vol. 51, no 1, 2012 Jan, pp. 86-97.e8, DOI:10.1016/j.jaac. 2011.10.015, PMID 22176942

79. EJ. Sonuga-Barke, D. Brandeis; S. Cortese; D. Daley; M. Ferrin; M. Holtmann; J. Stevenson; M. Danckaerts; S. van der Oord; M. Döpfner; RW. Dittmann, Nonpharmacological interventions for ADHD: systematic review and meta-analyses of randomized controlled trials of dietary and psychological treatments., in Am J Psychiatry, vol. 170, $\mathrm{n}^{\circ} \quad 3, \quad$ Marzo 2013, pp. 275-89, DOI:10.1176/appi.ajp.2012.12070991, PMID 23360949

80. Millichap JG, Yee MM, The diet factor in attentiondeficit/hyperactivity disorder, in Pediatrics, vol. 129, $\mathrm{n}^{\circ}$ 2, Febbraio 2012, pp. 330-7, DOI:10.1542/peds.2011-2199, PMID 22232312.

81. Konikowska K, Regulska-Ilow B, Rózańska D, The influence of components of diet on the symptoms of ADHD in children, in Rocz Panstw Zakl Hig, vol. 63, n 2, 2012, pp. 127-34, PMID 22928358

82. Anja Königs and Amanda J Kiliaan, Critical appraisal of omega-3 fatty acids in attention-deficit/hyperactivity disorder treatment, Neuropsychiatr Dis Treat. 2016; 12: 1869-1882

83. A.J. Richardson, Omega-3 fatty acids in $A D H D$ and related neurodevelopmental disorders, International Review of Psichiatrt, Issue e, Vol. 18, 2006 